ingen involverte at registra skal kome i vanry grunna lekkasjar eller misbruk av personopplysningar. Det er såleis fullt mogeleg å kombinere kvalitet og datatryggleik, slik at vi får gode register som alle har tillit til.

Vi kjenner ikkje til misbruk av data frå alle åra med sentrale helseregister med personidentifikasjon. I mangel på slike døme konstruerer Haug opp fantasifulle telefonoppringingar ho ikkje ville like å få av ukjende personar som sat med helseregisteropplysningar om henne. Ho bør heller konsentrere seg om realitetane.

Både Haug og Legeforeningen er truleg i utakt med fagmiljøa i denne saka. Det er paradoksalt at frykta for personvernet er så uttala her i landet når det gjeld akkurat helseregistra, der nytteverdien er stor og misbrukspotensialet tydelegvis er lite.

\section{Reidar Kvåle}

dagleg leiar i Norsk Intensivregister

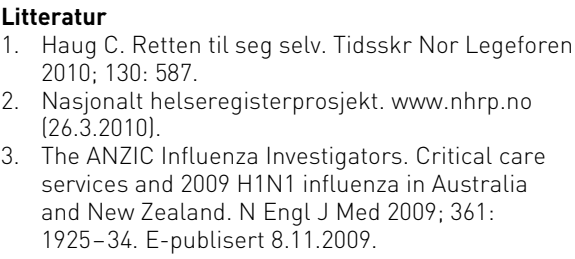

\section{Kirurgiske refleksjoner}

Kristoffer Lassen gir i en lederartikkel i Tidsskriftet nr. 7/10 til beste sitt syn på anestesilegenes plass $\mathrm{i}$ behandlingen av kirurgiske pasienter (1). Artikkelen er krydret med selektive litteraturhenvisninger og rene uetterretteligheter og stiller redaksjonens evne til å kvalitetssikre innholdet i relieff.

Lassen mener at «... kirurgen alene er den pasientansvarlige lege [...] etter forskriften [...]. Bare kirurgen har det totale ansvar for pasienten fra sykdommen mistenkes og utredes til behandlingen avsluttes [...]». «Forskrift om pasientansvarlig lege» er kanskje vanskelig å forstå, men selv Lassen må ha observert at ordet «kirurg» ikke er anvendt der - det er opp til virksomhetens ulike nivåer, ikke våre kirurgiske kolleger, å avgjøre hvem som er pasientansvarlig lege (2). Behovet for å samordne aktiviteten til mange ulike spesialister gjør at anestesileger ved landets intensivavdelinger i lang tid har påtatt seg denne rollen for de aller sykeste pasientene. Dette ansvaret strekker seg selvsagt langt utover det operative døgnet.

Lassen ønsker oss anestesileger «raust» velkommen i et kirurgisk fellesskap (les: avdelinger med kirurgisk ledelse), der vi vil kunne bidra til en mer fysiologisk tilnærming til pasienter i et perioperativt forløp. Han referer selektivt til en svensk ikke-randomiserte studie, med historiske kontroll- personer, der effekten av intensivmedisinske innsatsgrupper på dødeligheten i sykehus tjener som begrunnelse for å ville involvere anestesilegene $\mathrm{i}$ arbeidet på sengepostene. Men han unnlater å referere til større studier og systematiske oversikter der effekten er langt mindre åpenbar (3). Norske anestesilegers erfaringer fra Australia og Storbritannia er dessverre at slike innsatsgrupper fungerer som en sovepute for kirurger som er glade for å slippe postarbeidet.

Forslag til omorganiseringer i helsetjenesten er ofte motivert av et ønske om å innplassere forslagsstilleren øverst i næringskjeden. Det er nok i et slikt perspektiv vi må forstå Lassens lederartikkel.

\section{Jon Henrik Laake}

Oslo

\section{Litteratur}

1. Lassen K. Hvor ble det av anestesilegene? Tidsskr Nor Legeforen 2010; 130: 720.

2. Forskrift om pasientansvarlig lege. Lovdata 2010. www.lovdata.no/for/sf/ho/xo-20001201-1218.html (12.4.2010)

3. McGaughey J, Alderdice F, Fowler R, et al. Outreach and Early Warning Systems (EWS) for the prevention of intensive care admission and death of critically ill adult patients on general hospital wards. Cochrane Database Syst Rev 2007; CD005529.

\section{Mobilstråling - en medisinsk debatt?}

I Tidsskriftet nr. 23/09 kritiserer fysikeren Vistnes (1) min bok Mobilstråling. Istedenfor saklige argumenter er det mistenkeliggjøring.

Ifølge Vistnes

blir det biolo-

giske reaksjoner

kun dersom vevet blir oppvarmet av strålingen. Han hevder dette med bakgrunn i retningslinjene til den internasjonale strålevernkommisjonen (ICNIRP). Disse ble fastsatt på bakgrunn av et referanseeksperimentet fra 1990-årene: Man fylte plastdukker med vann, bestrålte dem og målte temperaturen.

Bioinitiativ-rapporten viser at vannfylte plastdukker er en dårlig modell for mennesket (2). I denne dokumenteres biologiske reaksjoner ved eksponering for svak stråling. Rapporten er ikke gjennomført av «pressgrupper», som Vistnes insinuerer, den bygger på en samling av metaanalyser fra anerkjente forskere om relevant forskning frem til 2007, inklusive de studier som ikke viser effekt. Tar man denne rapporten til følge, bør det ikke lenger være legitimt å basere strålevernpolitikken på den hypotese at slike reaksjoner ikke eksisterer.
Grenseverdier må defineres på grunnlag av dokumentasjon. Også nyere resultater bekrefter Bioinitiativ-rapportens konklusjoner (3-6).

WHO-behandlingsopplegget for eloverfølsomme (7) bygger også på hypotesen at kun oppvarming skaper biologiske effekter De eloverfølsomme er oppgitt over det. Norske og svenske spørreundersøkelser (8) viser at feltsanering fører til varige forbedringer. Det bør derfor være kontraindisert å eksponere eloverfølsomme, men felteksponering er dessverre «offentlig helsepolitikk» i Norge. Erfaringer fra rammede kan ikke neglisjeres uten å fordømme en hel pasientgruppe som hypokondere. Respekt for pasientene må ikke være ren retorikk noe Vistnes gir inntrykk av.

Pasientenes erfaringer falsifiserer den «fysikalske hypotesen» - når stråling er årsaken, hjelper også sanering. WHObehandlingsopplegget er heller basert på strålepolitikk enn på biologisk-medisinske realiteteter. Enhver som opplever forbedringer pga. elsanering $(80 \%)$ motbeviser Vistnes' argumentasjon.

Både norsk ekspertise og strålevern er $i$ krise og mangler fotfeste i virkeligheten. Det er lite grunnlag for å betegne min bok som tendensiøs når den faktisk frembringer fakta og løsninger på problemet. Tiden er moden for en biologisk-medisinsk nyorientering i strålevernet.

\section{Walter Kraus}

$\emptyset y s l e b \emptyset$

\section{Litteratur \\ Vistnes Al. Tendensiøst om stråling. Anmeldelse av: Kraus W. Mobilstråling. Tidsskr Nor Legeforen 2009; 129: 2510-1. \\ 2. www.bioinitiative.org (15.10.2008). \\ 3. Hardell L, Carlberg M, Mild K. Epidemiological evidence for an association between use of wire- less phones and tumor diseases. Pathophysiology 2009; 16: 113-22 \\ 4. Hardell L, Carlberg M. Mobile phones, cordless phones and the risk for brain tumors. Int J Oncol 2009: 35: 5-17. \\ 5. Myung S, Ju W, McDonnell D et al. Mobile phone use and risk of tumors: a meta-analysis. Am J Clin Oncol 2009; 27: 5565-72. \\ 6. Lahkola A, Auvinen A, Raitanen J et al. Mobile phone use and risk of glioma i 5 North European countries. Int J Cancer 2007; 120: 1769-1775. \\ 7. WHO. Fact sheet 296 (2005). Electromagnetic fields and public health. www.who.int/ mediacentre/factsheets/fs296/en/index.html (13.4.2010) \\ 8. HET-projektet. Hälsoproblematik för elöverkäns- liga och tandvårdsskadade. Elöverkänsligas Riks- förbund. www.hetprojektet.info (30.12.2009).}

\section{Ufullstendig om antikolinergt syndrom}

En kasuistikk av Bjørn Brandsæter og medarbeidere i Tidsskriftet nr. 4/2010 om akutt antikolinergt syndrom hos en pasient har interesse utover det å gi en påminnelse om det sjeldne (1). Den kvinnelige pasienten skal angivelig ha hatt «uttalt anoreksi med 